\title{
Commemorating John F. MacDonald and the Art of Being a Mentor
}

\author{
Michael F. Jackson, Vania F. Prado, Marco A. M. Prado
}

\begin{abstract}
John F. MacDonald was a close friend and mentor whose life was ended far too soon on April 22, 2014. To those who knew him, John was an endearing blend of fiery Scotsman, compassionate socialist, dedicated family man, and tireless investigator. Those close to him valued his loyalty and friendship, relished his biting wit, and puzzled at his self-deprecating manner. His career spanned a remarkable period of discovery from the early identification of excitatory amino acid, to the molecular cloning and characterization of glutamate receptors and the elucidation of mechanisms responsible for regulating their function. A true pioneer in each of these areas, John's research has had a lasting impact on our understanding of excitatory synaptic transmission and its plasticity. Our intent in commemorating John's work is to focus on some notable discoveries that highlight the impact and innovative aspects of John's work. In doing so, we also wish to highlight just how greatly our understanding of the glutamate transmitter systems has advanced since the late 1970s, when John first launched his independent neuroscience career.
\end{abstract}

RÉSUMÉ: En souvenir de John F. MacDonald et de ses aptitudes de mentor. John F. MacDonald était un ami intime mais aussi un mentor dont la vie s'est terminée beaucoup trop abruptement le 22 avril 2014. Pour ceux et celles qui l'ont connu, John était à la fois un fougueux Écossais, un socialiste compatissant, un homme dévoué à sa famille et un chercheur infatigable. Ses proches appréciaient non seulement sa loyauté et son amitié mais savouraient également son esprit mordant et demeuraient perplexes face à son sens de l'autodérision. Sa carrière professionnelle a été jalonnée d'une remarquable série de découvertes, qu'il s'agisse du repérage, tôt dans sa carrière, des acides aminés excitateurs, du clonage moléculaire, de la caractérisation des récepteurs pour le glutamate et de la compréhension des mécanismes régissant leurs fonctions. Véritablement innovateurs dans chacun de ces domaines, les travaux de recherche de John ont eu une influence durable sur notre compréhension de la transmission synaptique excitatrice et de sa plasticité. Dans le cadre de cet hommage rendu à John, nous voulons mettre l'accent sur quelques-unes de ces percées notoires et mettre en relief l'impact et l'aspect innovateur de ses travaux. À cet effet, nous souhaitons rappeler à quel point notre compréhension des systèmes de transmission glutamatergique a progressé depuis la fin des années 1970, lesquelles coïncident avec les débuts de John dans les neurosciences.

Keywords: Electrophysiology, Cellular, Neurodegenerative diseases, Stroke, Neural plasticity

doi:10.1017/cjn.2016.272

Can J Neurol Sci. 2016; 43: 735-744

\section{INTRODUCTION}

Despite John F. MacDonald's (Figure 1) notable scientific achievements and numerous recognitions (e.g. Fellow of the Royal Society of Canada), John was a man of remarkable humility, preferring to have the spotlight shone on his trainees and close collaborators. A true gentleman, he was immensely generous of his time and advice and this, along with his scientific excellence, made John an exceptional mentor. Despite the intense pressures that are common within a laboratory environment, John fostered an environment that was scientifically thrilling, richly collaborative, personally rewarding, and welcoming to all. Notably, John was a pioneer in the field of translational neuroscience in Canada. He welcomed clinicians who lacked a strong scientific background into his laboratory, then worked collaboratively with them to address issues of clinical relevance. His studies aimed at preventing and treating cerebral ischemia are the best examples. John maintained close collaborations and lifelong friendships with many of his past trainees. Many more would continue to seek out his advice or simply drop by to "catch up," long after having left the laboratory.

A scientist, mentor, and administrator of great national and international stature, John's impact was especially noteworthy within the neuroscience community he called home for a great many years, namely that of the University of Toronto. As chair of the Department of Physiology at the University of Toronto, he was able to expand the faculty rank by developing a model of hiring that was relatively new at the time. New recruits were often cross-appointed to two departments, allowing costs to be divided. He imparted in the department the same type of atmosphere he had in his laboratory, certainly contributing to its national and international success. As noted in the text that follows, the MacDonald recruits to the department were exceptionally successful, garnering numerous career awards and other academic distinctions.

From the Department of Pharmacology and Therapeutics, College of Medicine,

University of Manitoba, Winnipeg, Manitoba, Canada (MFJ); Neuroscience Research Group, Kleysen Institute for Advanced Medicine, University of Manitoba, Winnipeg, Manitoba, Canada (MFJ); Robarts Research Institute, Schulich School of Medicine \& Dentistry, University of Western Ontario, London, Ontario, Canada (VFP, MAMP); Department of Anatomy and Cell Biology, Schulich School of Medicine \& Dentistry, University of Western Ontario, London, Ontario, Canada (VFP, MAMP); Department of Physiology and Pharmacology, Schulich School of Medicine \& Dentistry, University of Western Ontario, London, Ontario, Canada (VFP, MAMP).

Received February 22, 2016. Final Revisions Submitted April 30, 2016. Date of ACCEPTANCE May 23, 2016.

Correspondence to: Michael Jackson, Neuroscience Research Program SR426, University of Manitoba, 710 William Avenue, Winnipeg, Manitoba R3E 0Z3, Canada Email: michael.jackson@umanitoba.ca. Marco Prado, Robarts Research Institute, the University of Western Ontario, 1151 Richmond St. N, London, Ontario N6A 5B7, Canada. Email: mprado@ robarts.ca. 


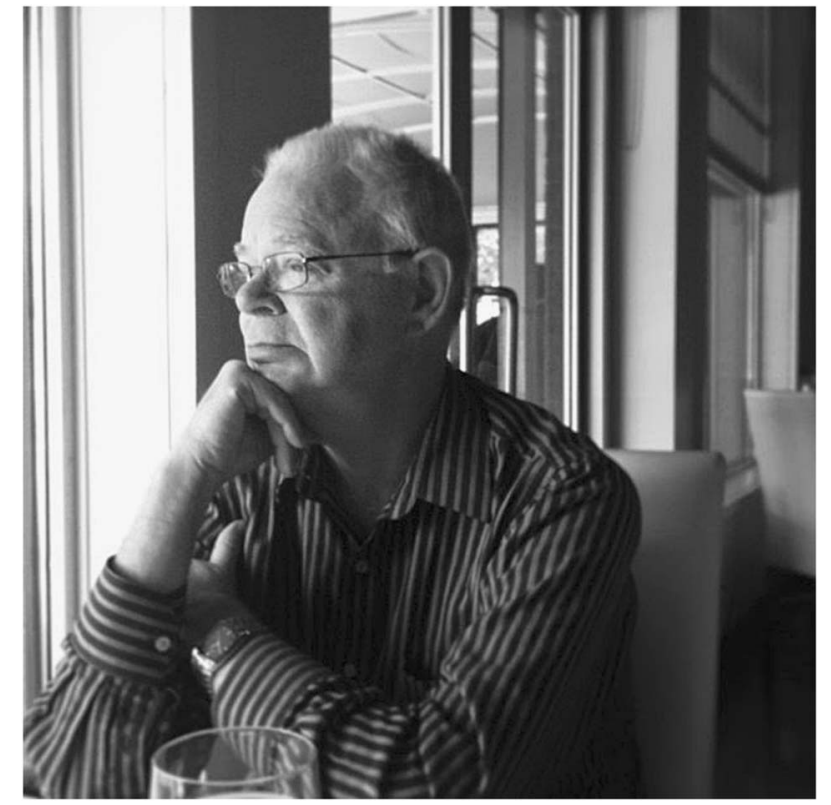

Figure 1: Photograph of John F. MacDonald taken by his wife, Lidia Brandes.

In the course of his scientific lifetime, John published more than 200 articles that have collectively been cited over 11,000 times (based on records at Scopus). To provide even a cursory overview of this scientific output would far exceed the confines of this review. Consequently, here we will focus on three areas in which John made notable contributions; the identification of the voltage-dependent behavior of $N$-methyl-D-aspartate receptors (NMDARs), pioneering work elucidating the role of posttranslational modifications in regulating NMDAR function, and groundbreaking studies characterizing the aberrant activation of $\mathrm{Ca}^{2+}$ permeable nonselective channels in models of stroke and neurodegeneration.

\section{Initial Characterization of the Voltage-DePENDENT BEHAVIOR OF NMDARS}

In considering these early MacDonald publications retrospectively, the reader is reminded that this work originated before the molecular identification of glutamate ionotropic receptors (iGluRs) via cloning between the years 1989 and 1992. ${ }^{1}$ In fact, in the late 1970s/early 1980 s, some doubt remained concerning the role of glutamate as the main excitatory transmitter in the central nervous system. Though proof of glutamate's role as an excitatory amino acid (EAA) was lacking, substantive progress was being made in establishing the existence of multiple receptors for EAAs. The identification of EAA receptor (EAAR) subtypes was made possible through the identification of the agonists NMDA, ${ }^{2,3}$ kainate, ${ }^{4}$ and quisqualate. ${ }^{5}$ Quisqualate was later superseded by $\alpha$-amino-3-hydroxy-5-methyl-4-isoxazolepropionic acid (AMPA) as an iGluR subtype defining agonist. ${ }^{6}$ Particularly convincing at this time was the distinction between NMDA versus non-NMDA receptors (quisqualate/AMPA and kainate). This was first based on the observation that responses to NMDA, but not to quisqualate or kainate, could be blocked by elevated extracellular concentrations of $\mathrm{Mg}^{2+7,8}$ Although the differential sensitivity of EAARs to $\mathrm{Mg}^{2+}$ was recognized, the mechanisms underlying the selective inhibition of NMDA responses by $\mathrm{Mg}^{2+}$ was not. Suggested mechanisms included that $\mathrm{Mg}^{2+}(1)$ antagonizes NMDA responses at the level of the receptor, ionophore, or other site or (2) exerts a stabilizing effect on the neuronal membrane or (3) associates with selected agonists and reduces their availability for receptor binding. $7,9,10$

Although progress had been made in characterizing the pharmacological properties of EAARs, progress in characterizing the conductance associated with NMDA and non-NMDA receptors lagged behind. One of the contentious issues of the day was to define the ionic species that permeate each channel when opened. More puzzling, was evidence that the application of selected EAAs, including DL-homocysteic acid and NMDA, is associated with a membrane conductance decrease rather than increase, ${ }^{11}$ anticipated on the basis of agonist-induced opening of a receptor associated ionophore. The majority of the work undertaken at this time, including the work by Engberg et al (1978), ${ }^{11}$ was performed using microiontophoresis to administer EAAs during in vivo recordings. These approaches made progress in advancing our understanding of conductance mechanisms associated with EAARs difficult for a number of reasons: (1) stable long-term recordings were more difficult to maintain because of cardiac and respiratory movements; (2) use of anesthetics could have a confounding influence on the responses generated by EAAs; (3) uptake mechanisms, which limit the response to applied EAAs, are more prominent in intact preparations maintained at body temperature; (4) the ionic composition of the extracellular milieu could not be precisely determined; and (5) the concentration of EAAs applied through microiontophoresis could not be estimated. These and other limitations were increasingly appreciated and noted in high-profile reviews of the era. ${ }^{10,12}$

It is within this state of knowledge of EAARs and the technical approaches used for their study that John launched his own laboratory in 1979 with a focus on identifying and characterizing the pharmacological and biophysical properties of EAARs. He initiated his independent career investigating current and voltage responses generated in neurons following the application of excitatory and/or inhibitory amino acids, their synthetically derived or naturally occurring analogues. John's prescient early adoption of primary neuronal cultures paired with rapid drug delivery by pressure application, allowed his group to make headway in understanding conductance mechanisms associated with EAARs.

In his first publications as an independent investigator, ${ }^{9,13,14}$ the MacDonald laboratory confirmed the initial report of a paradoxical conductance decrease in response to selected EAAs, now recognized as having in common the ability to strongly activate NMDARs (Figure 2A). Conversely, a strict conductance increase was observed in response to application of the non-NMDAR agonists, kainate and quisqualate. These findings were extended by demonstrating that the conductance decrease observed in response to NMDAR agonists was converted to an increase upon membrane depolarization. The conductance decrease observed, but not the increase, was selectively susceptible to elevated $\mathrm{Mg}^{2+}$ concentrations and coapplication of DL- $\alpha$-aminoadipate, one of the first relatively specific NMDAR antagonists. Importantly, conductance increases observed in responses to kainate were spared from the actions of both $\mathrm{Mg}^{2+}$ and DL- $\alpha$-aminoadipate. Although their significance was not yet fully appreciated at the time, these observations provided the first 
A Current-clamp
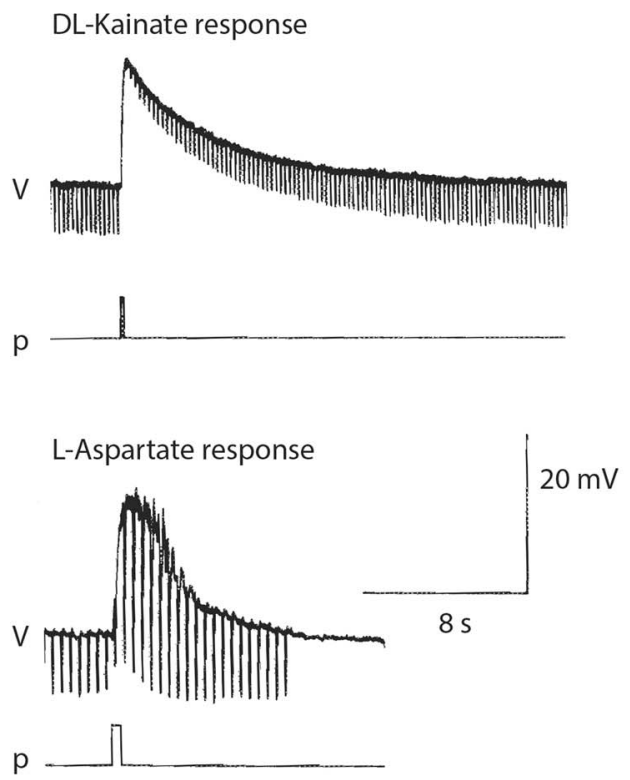

B

Voltage-clamp

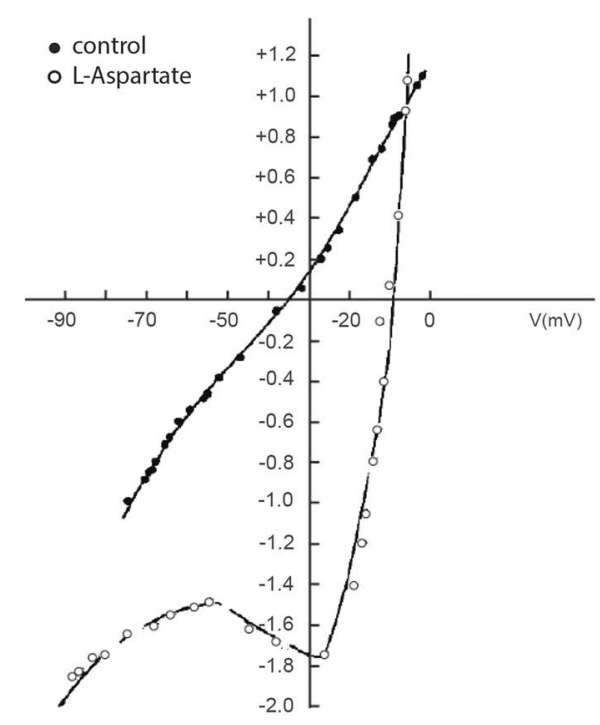

Figure 2: Voltage-dependent behavior of NMDA receptor responses. (A) Current-clamp recording of voltage response of cultured neurons to DL-Kainate $(100 \mu M$; top trace) and L-aspartate (100 $\mu M$; bottom trace), applied by pressure microperfusion. Application of kainate and aspartate evoked rapid membrane depolarizations ( $v$, voltage traces). Timing of agonist application shown on pressure trace (p). Vertical deflections represent membrane responses to superimposed negative current injections (each of $50 \mathrm{~ms}$ duration). Reduced membrane response to negative current injections during the kainate-evoked response is consistent with an increase in membrane conductance. Increased membrane response to negative current injections during the aspartate evoked was anomalous in suggesting a decrease in membrane conductance. From MacDonald and Wojtowicz (1980) with permission. (B) Current-voltage (I-V) relations in the presence (open circle) or absence (closed circle) of $L$-aspartate $(500 \mu M)$, applied by pressure microperfusion. I-V relations were generated from voltage-clamped cultured neurons. L-aspartic acid induces a region of negative slope conductance from -50 to $-26 \mathrm{mV}$. We now know that the region of negative slope corresponds to increased block of NMDARs by magnesium as the membrane potential is made more negative. From MacDonald et al (1982) with permission.

clue to the unique voltage-dependent behavior of NMDARs. They also strengthened accumulating evidence supporting the existence of multiple receptors for EAAs - in particular, that the receptor for kainate represents a distinct receptor class with distinct conductance properties.

All of the findings described so far were derived from experiments using current-clamp recordings whereby membrane depolarizations were recorded in response to the application of selected EAAs. By applying Ohm's law, changes in membrane conductance could be estimated by monitoring the change in voltage deflections evoked by repeated current injections superimposed upon the depolarizing response generated by applied EAAs. Several theories were advanced to explain the decrease in membrane conductance observed with applied NMDAR agonists, perhaps chief among them being the suggestion that this was due to the closing of voltage-dependent $\mathrm{K}^{+}$channels in response to membrane depolarization. ${ }^{15}$ Implicit with this stated mechanism is an acknowledgment of the inherent limitations of currentclamp recordings; that neuronal membrane conductance is highly nonlinear and varies with membrane potential resulting from changes in underlying voltage-dependent conductances. Recognizing this, MacDonald and Wojtowicz (1982) acknowledged that "A misinterpretation of the sign of $\Delta \mathrm{G}$ (i.e. whether conductance increased or decreased) arises when voltage deflections pass through the range of membrane potential where a region of negative slope conductance is present, or in other words, that range where a voltage-dependent current is activated"; and moreover, that "a highly voltage-dependent increase of GNa or Gca (i.e. $\mathrm{Na}^{+}$or $\mathrm{Ca}^{2+}$ conductance, respectively) could provide an explanation for an apparent decrease in Gm (i.e. membrane conductance) equally as well as a decrease in GK (i.e. $\mathrm{K}^{+}$ conductance)." 9 In keeping with this, they acknowledged that more definitive evidence concerning the nature of the conductance changes elicited by NMDAR agonists would require conductance measurements using voltage-clamp techniques and then proceeded to undertake such measurements. ${ }^{16}$ Taking advantage of the ease of access and stability afforded by the use of primary cultured neurons, they performed voltage-clamp recordings and evaluated the current-voltage (I-V) characteristics of the conductance evoked by L-aspartate. They observed that L-aspartate, now recognized as a specific NMDAR agonist, induces a region of negative slope conductance over a range of potentials from -50 to $-26 \mathrm{mV}$ and thus demonstrated conclusively the voltage-dependent behavior of NMDARs (Figure 2B). Influenced by these reports of MacDonald and colleagues, the mechanistic basis of voltage-dependent NMDAR channel behavior was established shortly thereafter when it was shown that NMDARs are subject to voltage-dependent block by $\mathrm{Mg}^{2+} \cdot 17,18$ 
These advances in understanding the mechanisms underlying the voltage-dependent properties of NMDARs coincided with parallel progress in understanding their key contribution to the induction of synaptic plasticity (see Collingridge ${ }^{19}$ for review). Making use of the recently introduced specific NMDAR antagonist, (D,L)-2-amino-5-phosphonopentanoate (AP5), Collingridge et al $(1983)^{19}$ demonstrated that NMDARs are responsible for the induction of long-term potentiation (LTP) at the Schaffer collateral-commissural pathway. ${ }^{20}$ Intriguingly, they also noted that AP5 had no effect on baseline excitatory synaptic transmission or pre-established LTP. In contrast, $\gamma$-D-glutamylglycine, a weak antagonist of AMPA and kainate receptors, depressed synaptic transmission. This suggested that AMPA/kainate receptor subtypes mediate fast excitatory synaptic transmission, whereas NMDARs serve as a trigger for the induction of synaptic plasticity. But the mechanisms permitting the differential contribution of each receptor subtype to baseline transmission versus induction of plasticity were not recognized. The discovery of the voltage-dependent block of NMDARs by $\mathrm{Mg}^{2+}$ allowed the now-established role of the NMDAR as a coincident detector and gate for the induction of synaptic plasticity to be proposed on theoretical grounds, ${ }^{21}$ supporting Hebb's postulate for how memories are formed.

Additional noteworthy discoveries from the MacDonald laboratory during this era include results from a series of detailed and elegant studies characterizing the mechanisms of block of NMDARs by the dissociative anesthetics ketamine and phencyclidine, ${ }^{22-25}$ in which the voltage-dependent block of NMDARs by ketamine and phencyclidine was first described. This was the first example of John's interest in addressing a clinical problem and of forging strong ties with a physician trainee, namely Beverley Orser, a wellrecognized clinician-scientist (departments of Physiology and Anesthesia, University of Toronto).

\section{Posttranslational Regulation of igluRs via Serine/ Threonine and Tyrosine Phosphorylation}

The characterization of the voltage-dependent properties of NMDARs and identification of its dependence on $\mathrm{Mg}^{2+}$, coupled with knowledge regarding the contribution of NMDARs to the induction of synaptic plasticity, led to an explosion of interest in understanding the regulation and function of NMDARs. The elucidation of the important role of protein phosphorylation in regulating iGluRs, and in particular NMDARs, and the functional consequence of changes in NMDAR phosphorylation on the induction of synaptic plasticity would come to represent an area to which John made important contributions over the ensuing years. Highlighting the flurry of interest and intensive research activity in this area, many of the MacDonald laboratory's groundbreaking findings were reported alongside analogous findings by competing laboratories, often in the very same journal issue.

\section{INITIAL ChaRaCTERIZATION OF THE REQUiREMENT FOR Protein Phosphorylation in Maintaining igluR Function}

Among the earliest evidence that protein kinase activity can regulate ion channel function stemmed from studies in which purified catalytic fragments of protein kinase A (PKA), or its specific inhibitor protein kinase inhibitor, were injected into neurons from the mollusc Aplysia. ${ }^{26,27}$ The advent and subsequent rapid adoption of patch-clamp techniques introduced by
Neher and Sakmann ${ }^{28}$ would greatly facilitate the elucidation of the role of protein phosphorylation in regulating ion channel function in mammalian neurons. The whole-cell patch-clamp configuration, which allows for the exchange of soluble factors between the intracellular milieu and pipette solution, would prove especially beneficial in this respect. Using large-tipped electrodes (tip diameter $>1 \mu \mathrm{m}, 3-4 \mathrm{M} \Omega$ resistance) routinely used for whole-cell recordings, the MacDonald laboratory would provide the first evidence that NMDARs can be regulated by phosphorylation. In their studies, they noted that NMDARs' currents would progressively rundown over time unless a means of preserving intracellular adenosine triphosphate (ATP) levels was included in their patch pipette solutions. ${ }^{29,30}$ Especially effective was an ATP regenerating solution ${ }^{31}$ containing ATP, phosphocreatine, and creatine phosphokinase (Figure 3). In contrast, inclusion of a nonhydrolysable analogue of ATP $(\beta, \gamma$-methylene ATP) was ineffective, implying that hydrolysis of ATP, necessary for phosphorylation reactions, rather than its mere presence was required. The findings led Mody, Salter, and MacDonald ${ }^{30}$ to state: "On the basis that high-energy phosphates promote phosphorylation we suggest that protein phosphorylation regulates ion flow through the NMDA channel." And: "Intracellular phosphorylation could be a means of functional control of NMDA receptor channels, as important as the effects of extracellular regulatory factors like $\mathrm{Mg}^{2+17,18}$ $\mathrm{Zn}^{2+}, 32,33$ and glycine.",34,35

The MacDonald laboratory would soon provide more definitive functional evidence supporting that iGluRs, in this case AMPA/kainate receptors, can be regulated by phosphorylation. $^{36,37}$ These experiments were spearheaded by Lu-Yang Wang (then a PhD candidate and now at the SickKids Research Institute, University of Toronto) who would remain a lifelong friend of the MacDonalds. They first demonstrated that AMPA/ kainate receptors rundown during intracellular dialysis unless an ATP-regenerating system was included in patch solutions, supporting that the maintenance of intracellular phosphorylation determines the magnitude of AMPA/kainate receptor-mediated currents. In an experimental tour-de-force, the authors then exploited the ability to alter the contents of the pipette solution through internal perfusion during a whole-cell recording. They demonstrated that intracellular perfusion with a solution containing cAMP and the catalytic subunit of PKA could reverse the rundown of AMPA/kainate receptor currents observed during an initial recording period in which the same neuron was perfused with a control recording solution. The reported ability of PKA to functionally regulate AMPA/kainate receptors was published in notable company as comparable findings were reported by Paul Greengard and associates ${ }^{38}$ in the same issue of Science. The significance of their findings were immediately appreciated by Wang, Salter, and MacDonald, ${ }^{36}$ who stated: “...persistent protein kinase activity is associated with the early postsynaptic events leading to induction of long-term potentiation in the hippocampus. Regulation of AMPA-kainate receptors by such activity may thus contribute to some aspects of postsynaptic plasticity." 39,40

At this time, it was recognized that the rise in current amplitude observed in response to increased protein kinase activity could proceed via phosphorylation of an AMPA/kainate receptor subunit or of a regulatory protein associated with the channel. This was addressed by Wang and colleagues (1993) in the very first study to exploit knowledge of the primary sequence of a recently 
control intracellular solution

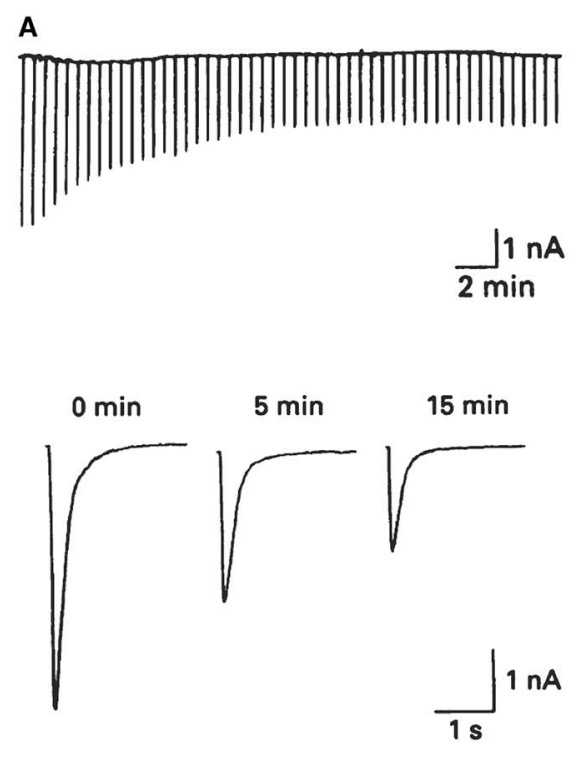

B
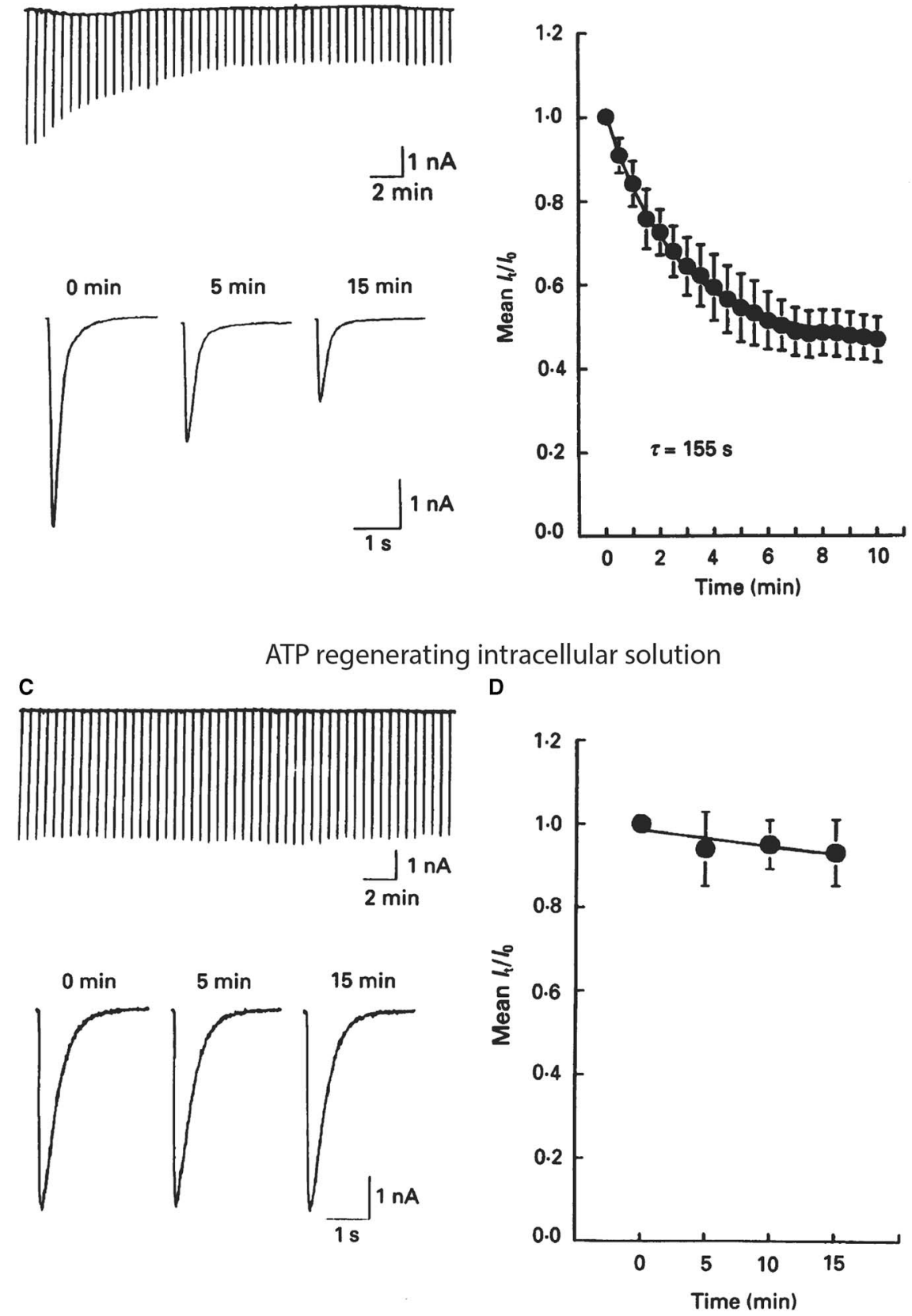

Figure 3: Rundown of NMDAR prevented by ATP regenerating solution. (A) Rundown of currents evoked by L-aspartate applied to cultured neurons when the intracellular recording solution does not contain high energy phosphates. Note the progressive amplitude decline of L-aspartate-evoked currents over time. Expanded traces show representative responses from the times indicated. (B) Summary graph from a series of comparable recordings in which current responses were normalized to the initial response recorded at $t=0 .(C)$ Rundown of currents evoked by L-aspartate is prevented when the intracellular recording solution contains an ATP regenerating solution containing ATP, phosphocreatine, and creatine phosphokinase. (D) Summary graph from a series of comparable recordings in which current responses were normalized to the initial response recorded at $t=0$. From MacDonald et al (1989) with permission.

cloned iGluR (GluR6) ${ }^{41}$ and site-directed mutagenesis to abrogate consensus phosphorylation sites for PKA. The ability of PKA to augment kainate responses was abolished by alanine substitution at presumed serine phosphorylation sites of the GluR6 subunit when expressed in HEK293 cells. Corroborating findings were published the very same week by the Huganir laboratory. ${ }^{42}$ 
Particularly compelling evidence that NMDARs are regulated by phosphorylation/dephosphorylation would come from the groups of MacDonald, ${ }^{43}$ Salter, ${ }^{44}$ and Mody, ${ }^{45}$ who independently reported in the same issue of Nature the important role of serine/threonine and tyrosine phosphatases in regulating the function of NMDARs. The coinciding publications were notable for the fact that both Mody and Salter had trained with John as postdoctoral fellows. By now a recurring theme with former trainees, Mike Salter and John would continue to collaborate and maintain a close friendship to the very end. In the studies reported in Nature, the MacDonald group used the phosphatase inhibitors okadaic acid and calyculin A, at concentrations selective for the serine/threonine phosphatases PP1 and PP2A, and demonstrated a resulting enhancement of NMDAR channel activity. They exposed inside-out membrane patches from hippocampal neurons to purified PP1 or PP2A and recorded the effect upon NMDAR single-channel activity. Exposure to either PP1 or PP2A reduced NMDAR open probability; in each case, this effect could be reversed by subsequent application of okadaic acid. In concert with evidence from Lieberman and Mody showing that NMDAR are also subject to regulation by the $\mathrm{Ca}^{2+}$-dependent serine/ threonine phosphatase PP2B (or calcineurin), these findings demonstrated the ability of phosphatases to constrain the activity of NMDARs. These results provided definitive evidence that endogenous serine/threonine protein kinases are constitutively active in maintaining the function of NMDARs. The work was important in providing a functional correlate to emerging biochemical evidence demonstrating that NMDARs are indeed subject to serine/threonine phosphorylation. ${ }^{46}$ In a similar vein, Wang and Salter (1994) used comparable methodologies to provide the first evidence that NMDARs are regulated by protein tyrosine kinases and phosphatases. Collectively, these studies nicely complemented other evidence that NMDARs could be regulated by protein kinases. ${ }^{4-50}$ This effectively established the now well-recognized concept that the level of NMDAR activity is governed by the balance of kinase and phosphatase activity.

As is the hallmark of ground breaking discoveries, the findings from the MacDonald laboratory, proving that ionotropic glutamate receptors are regulated via protein phosphorylation, helped establish an entirely new area of study focused on elucidating how cell signaling events are orchestrated to regulate glutamate receptors, synaptic transmission, and plasticity. John and colleagues would go on to make major contribution in each of these areas, most notably in studies examining the regulation of NMDARs and consequent induction of synaptic plasticity by G-protein coupled receptors for glutamate (mGluR5 $5^{51}$ and mGluR2/3 ${ }^{52}$ ), acetylcholine $\left(\mathrm{mAchR}^{53,54}\right)$, pituitary adenylate cyclase-activating polypeptide (PAC1R), ${ }^{55,56}$ vasoactive intestinal peptide (VPACR), ${ }^{57}$ and dopamine $\left(\mathrm{D} 1 \mathrm{R}^{56}\right.$ and $\left.\mathrm{D} 2 \mathrm{R}^{58,59}\right)$.

\section{Aberrant $\mathrm{CA}^{2+}$ Permeable Nonselective Channel ACtivation in Models of Stroke and Neurodegenerative DISEASE}

The introduction of AP5, the first NMDAR selective antagonist, ${ }^{60}$ was followed by the first evidence implicating NMDARs as a causative agent underlying excitotoxicity. ${ }^{61}$ The effectiveness of NMDAR antagonists in cell culture and animal models of stroke firmly established NMDAR-initiated neuronal injury as the dominant conceptual model not only for stroke-related neuronal cell death, but more broadly for neurodegenerative diseases. These and other findings led to great enthusiasm and optimism that pharmacological antagonism of NMDAR-mediated neurotoxicity could protect against brain ischemia ${ }^{62}$ and on this basis clinical stroke trials of agents targeting the NMDAR were initiated. However, NMDAR antagonists failed to provide neuroprotection. Moreover, in many patients treatment had to be terminated because of side effects, which included psychosis. Accordingly, the field moved from great optimism to great pessimism about the prospects for NMDAR antagonists in treating brain ischemia. ${ }^{63,64}$

In light of their effectiveness in animal models, the failure of drugs targeting NMDARs was especially perplexing, and many proposals have been advanced to explain their failure. These include that the therapeutic window for drugs targeting NMDARs is quite narrow and that block of NMDAR was associated with dose-limiting side effects, including severe psychosis. These facts were acknowledged by John and colleagues in a commissioned opinion article in which they lament; "So we are left in a quandary. Blocking NMDA receptors is potentially neuroprotective in stroke but ideally the blocker should be present during the stroke and the patient must put up with being psychotic. An alternative approach is to abandon targeting NMDA receptors entirely, in favor of potential downstream "cell death' targets." 65 At the time of this opinion article, this approach was already established in the MacDonald laboratory and would represent an area of focus for years to come. Key strategies used for identifying/targeting downstream cell death targets included interfering with the assembly of protein signaling complexes that tether components responsible for initiating cell death to NMDARs and preventing the activation of additional sources of $\mathrm{Ca}^{2+}$ entry recruited downstream of the NMDAR. Much of this work was undertaken in close collaboration with the laboratory of Michael Tymianski, another clinician-scientist who trained in the MacDonald laboratory and would remain a friend and longstanding collaborator of John's.

\section{UnCOUPLING OF NMDARs FroM THE $\mathrm{CA}^{2+}$-DEPENDENT Production of Cell Damaging Oxidative/Nitrosative STRESS}

Despite its recognized importance to neurological function in health and in disease, the weight of evidence to date suggests that NMDARs are not a viable therapeutic target, at least not for agents that indiscriminately reduce channel function. There are exceptions to this rule because a few select drugs are used clinically in a limited capacity (e.g. ketamine, memantine), but certainly not in the context of neuroprotection in stroke. And yet from the quagmire of more than 30 years of research seeking to identify neuroprotective agents based on the excitotoxic theory of ischemic stroke, a promising neuroprotective agent targeting the NMDAR emerged through research headed by Michael Tymianski in close collaboration with John and others, including Mike Salter and Yu-Tian Wang. Counterintuitively, the drug in question does not inhibit NMDAR function at all. Rather, it uncouples the NMDAR from a scaffolding complex largely responsible for excitotoxicity initiated following aberrant NMDAR-mediated $\mathrm{Ca}^{2+}$ entry. Neuroprotection by TAT-N2B9c, now renamed NA-1, in rodent stroke models ${ }^{66-68}$ has been extended to non-human primates ${ }^{69,70}$ and more recently humans. ${ }^{71}$ Of note, a phase I dose escalation trial in 
healthy volunteers showed that NA-1 administration was well-tolerated, without evidence of drug-related adverse events. NA-1 is currently in a trial called FRONTIER (Field Randomization of NA-1 in Early Responders), which aims to have paramedics administer NA-1 within 3 hours of symptom onset to patients with suspected acute stroke. If successful, the validation of such an approach may not only provide protection, but also extend the narrow window (currently only 3-4.5 hours) for treating patients with clot busting agents. NA-1 represents the lead therapeutic compound of NoNo Inc, a company headed by Michael Tymianski, of which John was a founding member and served on the Scientific Advisory Board.

\section{Contribution of $\mathrm{CA}^{2+}$ Permeable Nonselective Cation Channels to Excitotoxicity}

The failure of human stroke trials forced a critical reevaluation of the excitotoxic model of stroke with an eye toward uncovering NMDAR-independent mechanisms that contribute to cell death. With this in mind, and in conjunction with Michael Tymianski's group, the MacDonald laboratory probed for previously unrecognized contributors to anoxic cell death. They began by reexamining the effects of NMDARs blockers on anoxic cell death in cultured neurons. A key initial finding was that an antiexcitotoxic cocktail of blockers targeting glutamate receptors (i.e. AMPARs and NMDARs) and voltage-gated $\mathrm{Ca}^{2+}$ channels could prevent cell death resulting from brief (1 hour) but not extended episodes of oxygen-glucose deprivation (OGD; 1.5 hours or more). Cell death associated with extended OGD remained $\mathrm{Ca}^{2+}$ dependent and involved the entry of $\mathrm{Ca}^{2+}$ from the extracellular space. This suggested that additional routes of $\mathrm{Ca}^{2+}$ entry, distinct from those gated by NMDARs and voltage-gated $\mathrm{Ca}^{2+}$ channels, were recruited with delay during extended OGD. Conventional pathways for $\mathrm{Ca}^{2+}$ uptake, including $\mathrm{Na}^{+} / \mathrm{Ca}^{2+}$ exchanger, were ruled out, implying that a previously unrecognized $\mathrm{Ca}^{2+}$ permeable conductance was responsible. How then could they identify the conductance involved? Electrophysiological evidence from recordings conducted in cultured neurons exposed to chemical anoxia, combined with knowledge from past studies conducted by the MacDonald laboratory would provide key pieces to resolving this puzzle.

Electrophysiological recordings demonstrated that extended exposure of cultured neurons to chemical anoxia evoked a current that could be blocked by $\mathrm{Zn}^{2+}$ and the trivalent cation, $\mathrm{Gd}^{3+}$. I-V curves were outwardly rectifying and reversed at a membrane potential near $0 \mathrm{mV}$, supporting the involvement of a nonselective cation channel. Proof of $\mathrm{Ca}^{2+}$ permeability followed from the finding that the reversal potential was predictably altered by varying the extracellular concentration of $\mathrm{Ca}^{2+}$. Interestingly, reducing the extracellular concentration of $\mathrm{Ca}^{2+}$ dramatically increased the amplitude of the current induced by chemical anoxia and reduced current rectification. This suggested that the monovalent cation permeability is reduced by $\mathrm{Ca}^{2+}$ in a voltagedependent manner. On the basis of comparable sensitivity of OGD-evoked ${ }^{45} \mathrm{Ca}^{2+}$ uptake to $\mathrm{Gd}^{3+}$ during extended OGD, the conductance characterized biophysically during chemical anoxia was termed $\mathrm{I}_{\mathrm{OGD}}{ }^{66}$

Many of the attributes of $\mathrm{I}_{\mathrm{OGD}}$ matched those described by the MacDonald laboratory in studies exploring a calcium-sensing nonselective cation channel $\left(\mathrm{I}_{\mathrm{csNSC}}\right){ }^{72}$ The identification of $\mathrm{I}_{\mathrm{csNSC}}$ stemmed serendipitously from experiments undertaken by the MacDonald laboratory while exploring mechanisms contributing to $\mathrm{Ca}^{2+}$-dependent inactivation of NMDARs. The MacDonald laboratory and others had shown that $\mathrm{Ca}^{2+}$ entry via NMDARs recruits a negative feedback mechanism that limits the pathological entry of $\mathrm{Ca}^{2+}$. $\mathrm{Ca}^{2+}$-dependent inactivation of NMDARs, initiated when $\mathrm{Ca}^{2+} / \mathrm{CaM}$ associate with the $\mathrm{C}$-term tail of the GluN1 subunit, ${ }^{73}$ is routinely studied by comparing the NMDA-evoked responses recorded in the presence or absence of extracellular $\mathrm{Ca}^{2+}$. Characteristically, when conducting these experiments, $\mathrm{Ca}^{2+}$ is reduced or entirely eliminated only from the NMDA-containing solution under the assumption that the application of a low $\mathrm{Ca}^{2+}$ solution would not by itself initiate a response. Quite surprisingly, no one had tested this explicitly by conducting a simple and necessary control experiment, namely, to apply a low $\mathrm{Ca}^{2+}$ containing solution and determine whether a membrane response is elicited. The MacDonald laboratory noted that graded decreases in the extracellular concentration of $\mathrm{Ca}^{2+}$ (by as little as $100 \mu \mathrm{M}$ ) evoked graded increases in the amplitude of a nonselective cation current in hippocampal neurons. ${ }^{72}$ Like $\mathrm{I}_{\mathrm{OGD}}$, the current could be inhibited by a variety of divalent cations, including $\mathrm{Ca}^{2+}, \mathrm{Mg}^{2+}, \mathrm{Ba}^{2+}$, and $\mathrm{Cd}^{2+}$, and could be blocked by $\mathrm{Gd}^{3+} .{ }^{74}$ This revealed a close correspondence between the properties of $\mathrm{I}_{\mathrm{OGD}}$ and $\mathrm{I}_{\mathrm{csNSC}}$ and suggested that the same channel was likely responsible for both conductances. However, the identity of the channel responsible was not known and, on this basis, the MacDonald laboratory initiated a project to identify the channel underlying $\mathrm{I}_{\mathrm{csNSC}}$ through expression cloning in collaboration with Dr. Hubert Van Tol (a close friend and collaborator, deceased 2006). Notoriously labor-intensive, it is fortunate that the identification of the channel underlying $\mathrm{I}_{\mathrm{csNSC}}$ did not have to await completion of expression cloning. Instead, the answer would come from efforts aimed at cloning transient receptor potential (TRP) channels. ${ }^{75}$

The identification of TRPM7 and characterization of key properties, ${ }^{76}$ matching those reported for $\mathrm{I}_{\mathrm{OGD}}$ and $\mathrm{I}_{\mathrm{csNSC}}$, would provide the final piece of the puzzle, allowing the MacDonald and Tymianski laboratories to move forward and demonstrate that TRPM7 contributes to the conductance underlying $\mathrm{I}_{\mathrm{OGD}}{ }^{66}$ and $\mathrm{I}_{\mathrm{csNSC}}{ }^{77}$ Because specific pharmacological blockers for TRPM7 were not available, and in the absence of a TRPM7 knockout mouse, the critical evidence allowing this to be conclusively demonstrated was the use of RNA interference by small interfering RNA (siRNA), which up until that point had proven difficult to implement in cultured neurons. ${ }^{78}$ To suppress TRPM7 expression, primary cultured neurons were transfected with 21-nt

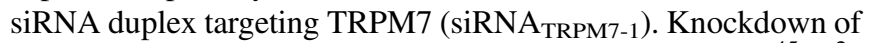
TRPM7 by siRNA ${ }_{\text {TRPM7-1 }}$ suppressed $\mathrm{I}_{\mathrm{OGD}}$, reduced ${ }^{45} \mathrm{Ca}^{2+}$ uptake, attenuated overall reactive oxygen specied production and extended the survival of cultured neurons exposed to OGD for up to 3 hours. In a follow-up articled published in 2009, the MacDonald group demonstrated that suppressing the expression of TRPM7, by viral mediated delivery of a specific short hairpin RNA sequence, conferred resistance to neuronal death after brain ischemia and preserved neuronal morphology and function. ${ }^{79}$ Also, it prevented ischemia-induced deficits in LTP and fearassociated and spatial navigational memory tasks. This study established that regional suppression of TRPM7 is feasible and well-tolerated, a critically important point if pharmacological inhibition of TRPM7 is to be exploited for therapeutic benefit. 
Collectively, these studies revealed a critical role for TRPM7 in mediating anoxic neuronal cell death.

Beyond TRPM7, the identification of additional $\mathrm{Ca}^{2+}$ permeable nonselective cation channels contributing to anoxic cell death would prove to be a very fertile area for John and his collaborators with important contribution of the MacDonald laboratory to the discovery of ASIC channels, ${ }^{80}$ pannexin channels, ${ }^{81}$ and TRPM2 ${ }^{82-85}$ This includes work completed in the last few days of John's life and just recently published, in which absence of TRPM2 was shown to decrease signs of neuronal toxicity and improve cognition in aged Alzheimer's model mice. ${ }^{85}$ The rationale for these studies, albeit speculative, derived in large part from work published by John and colleagues. ${ }^{82-84}$ These studies linked TRPM2 activation to cellular pathways associated with Alzheimer's disease pathology (e.g. increased oxidative stress, ${ }^{83}$ reduced neuronal oxidant defense, ${ }^{82}$ and increased GSK3 $\beta$ activity ${ }^{84}$ ). In the absence of experimental evidence directly linking TRPM2 to Alzheimer's disease pathology, a leap of faith was needed to initiate longitudinal behavioral studies in which TRPM2 knockout was crossed with Alzheimer's mouse model $\left(\mathrm{APP}_{\mathrm{Swe}} / \mathrm{PS} 1 \Delta \mathrm{E} 9\right)$. John had the conviction to initiate these studies when he approached us to undertake these experiments collaboratively. The positive outcome of these experiments is particularly rewarding to all of us.

\section{Mentoring And Administrative Achievements}

In addition to his remarkable scientific achievements, John assumed a number of leadership roles and made important contributions in this capacity as well. John had a significant role in the recent expansion of the Department of Physiology at the University of Toronto. This is one of the largest basic science departments in North America, with more than 120 faculty members. John was appointed initially at the Department of Pharmacology at the University of Toronto; however, he moved to the Department of Physiology in 1990 to become a founding member of the Medical Research Council (MRC) group in nerve cells and synapses, with Milton Charlton and several other colleagues. John served initially as graduate coordinator before assuming the Chairmanship of the Department (2001-2008). During his tenure, the department obtained 11 Canada Research Chairs, 3 Canadian Institutes of Health Research new investigator awards, a heart and stroke investigator award, and the Michael Smith Chair in neurosciences and mental health. John was well-known for his strategic partnerships with other departments and research institutes. It is no surprise that John is dearly missed by his departmental colleagues and friends (see http://www.physiology.utoronto.ca/history-department for a detailed account of John's leadership).

In 2008, John moved his laboratory to the University of Western Ontario, where he would work until his retirement in 2013. He assumed the position of director of the Robarts Research Institute for 3 years, a turbulent time because of the market crash of 2008. However, John continued to deliver outstanding advice and support for new investigators. The three of us are particularly grateful for his support, leadership, and insightful collaborations. His presence at Robarts had a huge impact on collaborative grants and manuscripts and our careers. We particularly miss our afternoon teas together in which ideas would flow freely, leading to several publications in collaboration despite the short period of time. ${ }^{54,85,86}$ Science was an important guide for John and even during his short time at Western he managed to publish outstanding work that has had a lasting impact on all around him. We are not just proud of having had time with him as a colleague, friend, and a mentor, we and all his collaborators and trainees are also extremely grateful to have had John impact our lives.

\section{ACKNOWLEDGMents AND FUnding}

The authors are grateful to Drs. Lu-Yang Wang and Beverley Orser for comments and helpful suggestions on the manuscript. Research in our laboratories is supported by the Canadian Institutes of Health Research (MOP-125901 to M.F.J.; MOP 136930, 126000, and 89919 to VFP and MAMP), Brain Canada (MAMP, VFP), The Weston Brain Institute (MAMP), and Natural Sciences and Engineering Research Council (VFP).

\section{DisClosures}

MFJ has served as principal investigator and received a research operating grant from Canadian Institutes of Health Research (CIHR); served as principal investigator and received an equipment infrastructure grant from CFI. VFP has received research grants and research support from CIHR, Brain Canada, and NSERC. MAMP has received contract research and research support from Merck; research grants and research support from CIHR, Weston Brain Institute, and Brain Canada.

\section{Statement of Authorship}

The manuscript was written and edited by MFJ, VFP, and MAMP.

\section{REFERENCES}

1. Hollmann M, Heinemann S. Cloned glutamate receptors. Annu Rev Neurosci. 1994;17:31-108.

2. Curtis DR, Watkins JC. Acidic amino acids with strong excitatory actions on mammalian neurones. J Physiol. 1963;166:1-14.

3. Watkins JC. The synthesis of some acidic amino acids possessing neuropharmacological activity. J Med Pharm Chem. 1962;91: 1187-99.

4. Shinozaki H, Konishi S. Actions of several anthelmintics and insecticides on rat cortical neurones. Brain Res. 1970;24:368-71.

5. Shinozaki H, Shibuya I. A new potent excitant, quisqualic acid: effects on crayfish neuromuscular junction. Neuropharmacology. 1974;13:665-72.

6. Krogsgaard-Larsen P, Honoré T, Hansen JJ, Curtis DR, Lodge D. New class of glutamate agonist structurally related to ibotenic acid. Nature. 1980;284:64-6.

7. Davies J, Watkins JC. Effect of magnesium ions on the responses of spinal neurones to excitatory amino acids and acetylcholine. Brain Res. 1977;130:364-8.

8. Evans RH, Francis AA, Watkins JC. Selective antagonism by Mg2+ of amino acid-induced depolarization of spinal neurones. Experientia. 1977;33:489-91.

9. MacDonald JF, Wojtowicz JM. The effects of L-glutamate and its analogues upon the membrane conductance of central murine neurones in culture. Can J Physiol Pharmacol. 1982;60: 282-296.

10. Nistri A, Constanti A. Pharmacological characterization of different types of GABA and glutamate receptors in vertebrates and invertebrates. Prog Neurobiol. 1979;13:117-235.

11. Engberg I, Flatman JA, Lambert JD. The action of N-methyl-D-aspartic and kainic acids on motoneurones with emphasis on conductance changes [proceedings]. Br J Pharmacol. 1978;64:384P-5P.

12. Mayer ML, Westbrook GL. The physiology of excitatory amino acids in the vertebrate central nervous system. Prog Neurobiol. 1987; 28:197-276. 
13. MacDonald JF, Porietis AV. DL-Quisqualic and L-aspartic acids activate separate excitatory conductances in cultured spinal cord neurons. Brain Res. 1982;245:175-8.

14. MacDonald JF, Wojtowicz JM. Two conductance mechanisms activated by applications of L-glutamic, L-aspartic, DL-homocysteic, $\mathrm{N}$-methyl-D-aspartic, and DL-kainic acids to cultured mammalian central neurones. Can J Physiol Pharmacol. 1980;58:1393-7.

15. Engberg I, Flatman JA, Lambert JD. The actions of excitatory amino acids on motoneurones in the feline spinal cord. J Physiol. 1979;288:227-61.

16. MacDonald JF, Porietis AV, Wojtowicz JM. L-Aspartic acid induces a region of negative slope conductance in the current-voltage relationship of cultured spinal cord neurons. Brain Res. 1982;237:248-53.

17. Mayer ML, Westbrook GL, Guthrie PB. Voltage-dependent block by $\mathrm{Mg} 2+$ of NMDA responses in spinal cord neurones. Nature. 1984;309:261-3.

18. Nowak L, Bregestovski P, Ascher P, Herbet A, Prochiantz A. Magnesium gates glutamate-activated channels in mouse central neurones. Nature. 1984;307:462-5.

19. Collingridge GL. The induction of N-methyl-d-aspartate receptordependent long-term potentiation. Philos Trans Biol Sci. 2003;358:635-41.

20. Collingridge GL, Kehl SJ, McLennan H. Excitatory amino acids in synaptic transmission in the Schaffer collateral-commissural pathway of the rat hippocampus. J Physiol. 1983;334:33-46.

21. Collingridge GL. Long term potentiation in the hippocampus: mechanisms of initiation and modulation by neurotransmitters. Trends Pharmacol Sci. 1985;6:407-11.

22. Honey CR, Miljkovic Z, MacDonald JF. Ketamine and phencyclidine cause a voltage-dependent block of responses to L-aspartic acid. Neurosci Lett. 1985;61:135-9.

23. MacDonald JF, Miljkovic Z, Pennefather P. Use-dependent block of excitatory amino acid currents in cultured neurons by ketamine. J Neurophysiol. 1987;58:251-66.

24. MacDonald JF, Bartlett MC, Mody I, et al. Actions of ketamine, phencyclidine and MK-801 on NMDA receptor currents in cultured mouse hippocampal neurones. J Physiol. 1991;432: 483-508.

25. Orser BA, Pennefather PS, MacDonald JF. Multiple mechanisms of ketamine blockade of N-methyl-D-aspartate receptors. Anesthesiology. 1997;86:903-17.

26. Castellucci VF, Kandel ER, Schwartz JH, Wilson FD, Nairn AC, Greengard P. Intracellular injection of the catalytic subunit of cyclic AMP-dependent protein kinase simulates facilitation of transmitter release underlying behavioral sensitization in Aplysia. Proc Natl Acad Sci U S A. 1980;77:7492-6.

27. Kaczmarek LK, Jennings KR, Strumwasser F, et al. Microinjection of catalytic subunit of cyclic AMP-dependent protein kinase enhances calcium action potentials of bag cell neurons in cell culture. Proc Natl Acad Sci U S A. 1980;77:7487-91.

28. Hamill OP, Marty A, Neher E, Sakmann B, Sigworth FJ. Improved patch-clamp techniques for high-resolution current recording from cells and cell-free membrane patches. Pflüg Arch Eur J Physiol. 1981;391:85-100.

29. MacDonald JF, Mody I, Salter MW. Regulation of N-methyl-Daspartate receptors revealed by intracellular dialysis of murine neurones in culture. J Physiol. 1989;414:17-34.

30. Mody I, Salter MW, MacDonald JF. Requirement of NMDA receptor/channels for intracellular high-energy phosphates and the extent of intraneuronal calcium buffering in cultured mouse hippocampal neurons. Neurosci Lett. 1988;93:73-8.

31. Forscher P, Oxford GS. Modulation of calcium channels by norepinephrine in internally dialyzed avian sensory neurons. J Gen Physiol. 1985;85:743-63.

32. Peters S, Koh J, Choi DW. Zinc selectively blocks the action of N-methyl-D-aspartate on cortical neurons. Science. 1987;236: 589-93.

33. Westbrook GL, Mayer ML. Micromolar concentrations of $\mathrm{Zn} 2+$ antagonize NMDA and GABA responses of hippocampal neurons. Nature. 1987;328:640-3.

34. Ascher P, Nowak L. Electrophysiological studies of NMDA receptors. Trends Neurosci. 1987;10:284-8.
35. Johnson JW, Ascher P. Glycine potentiates the NMDA response in cultured mouse brain neurons. Nature. 1987;325:529-31.

36. Wang LY, Salter MW, MacDonald JF. Regulation of kainate receptors by cAMP-dependent protein kinase and phosphatases. Science. 1991;253:1132-5.

37. Wang LY, Taverna FA, Huang XP, MacDonald JF, Hampson DR. Phosphorylation and modulation of a kainate receptor (GluR6) by cAMP-dependent protein kinase. Science. 1993;259:1173-75.

38. Greengard P, Jen J, Nairn AC, Stevens CF. Enhancement of the glutamate response by cAMP-dependent protein kinase in hippocampal neurons. Science. 1991;253:1135-8.

39. Malenka RC. Postsynaptic factors control the duration of synaptic enhancement in area CA1 of the hippocampus. Neuron. 1991;6: 53-60.

40. Malinow R, Schulman H, Tsien RW. Inhibition of postsynaptic PKC or CaMKII blocks induction but not expression of LTP. Science. 1989;245:862-6.

41. Egebjerg J, Bettler B, Hermans-Borgmeyer I, Heinemann S. Cloning of a cDNA for a glutamate receptor subunit activated by kainate but not AMPA. Nature. 1991;351:745-8.

42. Raymond LA, Blackstone CD, Huganir RL. Phosphorylation and modulation of recombinant GluR6 glutamate receptors by cAMP-dependent protein kinase. Nature. 1993;361:637-41.

43. Wang LY, Orser BA, Brautigan DL, MacDonald JF. Regulation of NMDA receptors in cultured hippocampal neurons by protein phosphatases 1 and 2A. Nature. 1994;369:230-2.

44. Wang YT, Salter MW. Regulation of NMDA receptors by tyrosine kinases and phosphatases. Nature. 1994;369:233-5.

45. Lieberman DN, Mody I. Regulation of NMDA channel function by endogenous $\mathrm{Ca}(2+)$-dependent phosphatase. Nature. 1994;369: 235-239.

46. Tingley WG, Roche KW, Thompson AK, Huganir RL. Regulation of NMDA receptor phosphorylation by alternative splicing of the C-terminal domain. Nature. 1993;364:70-3.

47. Aniksztejn L, Bregestovski P, Ben-Ari Y. Selective activation of quisqualate metabotropic receptor potentiates NMDA but not AMPA responses. Eur J Pharmacol. 1991;205:327-8.

48. Aniksztejn L, Otani S, Ben-Ari Y. Quisqualate metabotropic receptors modulate NMDA currents and facilitate induction of longterm potentiation through protein kinase C. Eur J Neurosci. 1992;4:500-5.

49. Chen L, Huang LY. Sustained potentiation of NMDA receptormediated glutamate responses through activation of protein kinase C by a mu opioid. Neuron. 1991;7:319-26.

50. Chen L, Huang LY. Protein kinase C reduces $\mathrm{Mg} 2+$ block of NMDA-receptor channels as a mechanism of modulation. Nature. 1992;356:521-3.

51. Kotecha SA, Jackson MF, Al Mahrouki AA, Roder JC, Orser BA, MacDonald JF. Co-stimulation of mGluR5 and NMDA receptors is required for potentiation of excitatory synaptic transmission in hippocampal neurons. J Biol Chem. 2003;278: 27741-9.

52. Trepanier C, Lei G, Xie YF, MacDonald JF. Group II metabotropic glutamate receptors modify N-methyl-D-aspartate receptors via Src kinase. Sci Rep. 2013;3:926.

53. Lu WY, Xiong ZG, Lei S, et al. G-protein-coupled receptors act via protein kinase $\mathrm{C}$ and $\mathrm{Src}$ to regulate NMDA receptors. Nat Neurosci. 1999;2:331-8.

54. Martyn AC, De Jaeger X, Magalhães AC, et al. Elimination of the vesicular acetylcholine transporter in the forebrain causes hyperactivity and deficits in spatial memory and long-term potentiation. Proc Natl Acad Sci U S A. 2012;109:17651-6.

55. Macdonald DS, Weerapura M, Beazely MA, et al. Modulation of NMDA receptors by pituitary adenylate cyclase activating peptide in CA1 neurons requires Galphaq, protein kinase $\mathrm{C}$, and activation of Src. J Neurosci. 2005;25:11374-84.

56. Yang K, Trepanier C, Sidhu B, et al. Metaplasticity gated through differential regulation of GluN2A versus GluN2B receptors by Src family kinases. EMBO J. 2012;31:805-16.

57. Yang $\mathrm{K}$, Trepanier $\mathrm{CH}, \mathrm{Li} \mathrm{H}$, et al. Vasoactive intestinal peptide acts via multiple signal pathways to regulate hippocampal NMDA receptors and synaptic transmission. Hippocampus. 2009; 19:779-89. 
58. Beazely MA, Tong A, Wei W-L, Van Tol H, Sidhu B, MacDonald JF. D2-class dopamine receptor inhibition of NMDA currents in prefrontal cortical neurons is platelet-derived growth factor receptor-dependent. J Neurochem. 2006;98:1657-63.

59. Kotecha SA, Oak JN, Jackson MF, et al. A D2 class dopamine receptor transactivates a receptor tyrosine kinase to inhibit NMDA receptor transmission. Neuron. 2002;35:1111-22.

60. Davies J, Francis AA, Jones AW, Watkins JC. 2-Amino-5phosphonovalerate (2APV), a potent and selective antagonist of amino acid-induced and synaptic excitation. Neurosci Lett. 1981;21: 77-81.

61. Simon RP, Swan JH, Griffiths T, Meldrum BS. Blockade of $\mathrm{N}$-methyl-D-aspartate receptors may protect against ischemic damage in the brain. Science. 1984;226:850-2.

62. Albers GW, Goldberg MP, Choi DW. N-methyl-D-aspartate antagonists: ready for clinical trial in brain ischemia? Ann Neurol. 1989;25:398-403.

63. Birmingham K. Future of neuroprotective drugs in doubt. Nat Med. $2002 ; 8: 5$.

64. Ikonomidou $\mathrm{C}$, Turski L. Why did NMDA receptor antagonists fail clinical trials for stroke and traumatic brain injury? Lancet Neurol. 2002;1:383-6.

65. MacDonald JF, Xiong ZG, Jackson MF. Paradox of $\mathrm{Ca}(2+)$ signaling, cell death and stroke. Trends Neurosci. 2006;29:75-81.

66. Aarts M, Iihara K, Wei WL, et al. A key role for TRPM7 channels in anoxic neuronal death. Cell. 2003;115:863-77.

67. Sattler R, Xiong Z, Lu WY, Hafner M, MacDonald JF, Tymianski M. Specific coupling of NMDA receptor activation to nitric oxide neurotoxicity by PSD-95 protein. Science. 1999;284(5421):1845-1848.

68. Sun HS, Doucette TA, Liu Y, et al. Effectiveness of PSD95 inhibitors in permanent and transient focal ischemia in the rat. Stroke. 2008;39:2544-53.

69. Cook DJ, Teves L, Tymianski M. Treatment of stroke with a PSD-95 inhibitor in the gyrencephalic primate brain. Nature. 2012;483:213-7.

70. Cook DJ, Teves L, Tymianski M. A translational paradigm for the preclinical evaluation of the stroke neuroprotectant Tat-NR2B9c in gyrencephalic nonhuman primates. Sci Transl Med. 2012;4: 154 ra133.

71. Hill MD, Martin RH, Mikulis D, et al. Safety and efficacy of NA-1 in patients with iatrogenic stroke after endovascular aneurysm repair (ENACT): a phase 2, randomised, double-blind, placebocontrolled trial. Lancet Neurol. 2012;11:942-50.
72. Xiong Z, Lu W, MacDonald JF. Extracellular calcium sensed by a novel cation channel in hippocampal neurons. Proc Natl Acad Sci U S A. 1997;94:7012-7.

73. MacDonald JF, Xiong XG, Lu WY, Raouf R, Orser BA. Modulation of NMDA receptors. Prog Brain Res. 1998;116:191-208.

74. Xiong ZG, MacDonald JF. Sensing of extracellular calcium by neurones. Can J Physiol Pharmacol. 1999;77:715-21.

75. Clapham DE, Runnels LW, Strubing C. The TRP ion channel family. Nat Rev Neurosci. 2001;2:387-96.

76. Runnels LW, Yue L, Clapham DE. TRP-PLIK, a bifunctional protein with kinase and ion channel activities. Science. 2001;291:1043-7.

77. Wei WL, Sun HS, Olah ME, et al. TRPM7 channels in hippocampal neurons detect levels of extracellular divalent cations. Proc Natl Acad Sci U S A. 2007;104:16323-8.

78. Krichevsky AM, Kosik KS. RNAi functions in cultured mammalian neurons. Proc Natl Acad Sci U S A. 2002;99:11926-9.

79. Sun HS, Jackson MF, Martin LJ, et al. Suppression of hippocampal TRPM7 protein prevents delayed neuronal death in brain ischemia. Nat Neurosci. 2009;12:1300-7.

80. Xiong ZG, Zhu XM, Chu XP, et al. Neuroprotection in ischemia: blocking calcium-permeable acid-sensing ion channels. Cell. 2004;118:687-98.

81. Thompson RJ, Jackson MF, Olah ME, et al. Activation of pannexin-1 hemichannels augments aberrant bursting in the hippocampus. Science. 2008;322:1555-9.

82. Belrose JC, Xie YF, Gierszewski LJ, MacDonald JF, Jackson MF. Loss of glutathione homeostasis associated with neuronal senescence facilitates TRPM2 channel activation in cultured hippocampal pyramidal neurons. Mol Brain. 2012;5:11.

83. Olah ME, Jackson MF, $\mathrm{Li} \mathrm{H}$, et al. Ca2+-dependent induction of TRPM2 currents in hippocampal neurons. J Physiol. 2009;587: 965-79.

84. Xie YF, Belrose JC, Lei G, et al. Dependence of NMDA/GSK3beta mediated metaplasticity on TRPM2 channels at hippocampal CA3-CA1 synapses. Mol Brain. 2011;4:44.

85. Ostapchenko VG, Chen M, Guzman MS, et al. The transient receptor potential melastatin 2 (TRPM2) channel contributes to $\beta$-amyloid oligomer-related neurotoxicity and memory impairment. J Neurosci. 2015;35:15157-69.

86. Ostapchenko VG, Beraldo FH, Mohammad AH, et al. The prion protein ligand, stress-inducible phosphoprotein 1, regulates amyloid- $\beta$ oligomer toxicity. J Neurosci. 2013;33:16552-64. 